\title{
Assessment of the water quality downstream of Red River in 2015 (Vietnam)
}

\author{
Đánh giá chất lương nước hạ lưu sông Hồng năm 2015 (Việt Nam) \\ Research article
}

Hoang, Thi Thu Hang${ }^{1,2}$, Nguyen, Trung Kien ${ }^{1}$, Le, Thi Phuong Quynh ${ }^{3}$, Dang, Dinh Kim ${ }^{1}$, Duong, Thi Thuy ${ }^{*}$

${ }^{1}$ Institute of Environmental Technology, Vietnam Academy of Science and Technology, 18 Hoang Quoc Viet Road, Cau Giay, Hanoi, Vietnam; ${ }^{2}$ Graduate University of Science and Technology, Vietnam Academy of Science and Technology, 18 Hoang Quoc Viet Road, Cau Giay, Hanoi, Vietnam; ${ }^{3}$ Institute of Natural Product Chemistry, Vietnam Academy of Science and Technology, 18 Hoang Quoc Viet Road, Cau Giay, Hanoi, Vietnam

\begin{abstract}
The Red River is strongly affected by climate and human activities, especially in the downstream area concentrating industrial zones, large urbans and powerful agricultural activities. The surface water is progressively susceptible to anthropogenic pollution. The physicochemical variables of surface water were determined at 5 sampling sites (Quyet Chien, Truc Phuong, Ba Lat, Nam Dinh and Gian Khau). At each site, water samples were taken monthly during the period from January to December 2015 to assess the effect of human activities on the surface water quality. The actual survey results showed that almost analyzed variables of the Red River water quality at the downstream were under the permitting limit values of the National technical regulation on surface water quality (QCVN 08:2015, column B1). The quality of water downstream of the Red River reaches the permissible value in surface water for the irrigation purposes, waterway and other purposes with low quality water requirements. The results provide dataset for subsequent studies on the annual variation of physical and chemical variables of Red River downstream water, as well as the scientific basis for the effective protection and management of water resources in Vietnam.
\end{abstract}

Sông Hồng bị ảnh hương mạnh mẽ bởi khí hậu và các hoạt động của con nguời, đặc biệt là ở khu vưc hạ luu, nơ tập trung nhiều khu công nghiệp, nhiều đô thị lớn và các hoạt động nông nghiẹp. Nước mặt đang dần bị ô nhiếm do con người. Các thông số hóa lý của nước mặt được xác định tại 5 trạm (Quyết Chiến, Trúc Phuoong, Ba Lạt, Nam Định và Gián Khẩu). Tại mối trạm, mẫu nuớc được lấy hàng tháng trong khoảng thời gian tù tháng 1 đến tháng 12 năm 2015 để đánh giá tác động của các hoạt động của con nguời đến chất luợng nước mặt. Kết quả khảo sát cho thấy, hầu hết các chỉ tiêu chất luợng nwớc ở ha luu của sông Hồng đều nằm trong giá trị giới hạn cho phép theo quy chuẩn kỹ thuật quốc gia về chất luợng nuớc mặt (QCVN 08: 2015, cột B1). Chất luợng nước ở hạ lưu của sông Hồng nằm trong giới hạn cho phép đối với mục đích tuới tiêu thủy lợi hoạc các muc đích sử dụng khác có yêu cầu nước chất luợng thấp. Kết quả thu được sẽ là co sở dũ liệu cho các nghiên cúu tiếp theo về sụ thay đổi hàng năm của chất luợng nước hạ lưu sông Hồng, và cũng sẽ là co sở khoa học cho việc bảo vệ và quản lý tài nguyên nuớc một cách có hiệu quả tại Việt Nam.

Keywords: $\quad$ human activities, water quality downstream, Red River, QCVN 08:2015

\section{Introduction}

The Red River is northern Vietnam's largest river with the catchments area of $156.451 \mathrm{~km} 2(51.2 \%$ of area belongs to Vietnam, $47.9 \%$ belongs to China and $0.9 \%$ belongs to Laos). It is an economic center of northern Vietnam concentrating industrial zones, large urbans and powerful agricultural activities. As known, the Red River is strongly affected by climate and human activities. In the upstream Red River basin, deforestation and land use changes are considered to cause a variety of environmental impacts such as increased flooding and dramatically increased soil erosion. In its downstream sector, the intensive farming practices with increasing use of nitrogen and phosphorus fertilizers, the increase of population, the economic 
industrial development and urbanization have strongly affected the water quality of the Red River system and also influenced the coastal zone ecosystem (Le et al., 2007; 2010). In particular the nitrogen and phosphorus exported from the watershed resulted not only in nutrient contamination of river water, but also in a risk for eutrophication, both in downstream, stagnant, sectors of the drainage network, particularly in the delta area, and in the coastal areas. Nutrients like nitrate and phosphate with high concentrations along with dissolved metals, chemicals, and refractory organics, will impact the quality of water body. Nitrate and phosphorus can cause eutrophication (excessive plant and algae growth) which in turn causes low dissolved oxygen levels due to plant respiration and microbial decomposition. Refractory organics are often carcinogenic, while heavy metals and other chemicals can be toxic to aquatic organisms. An increase in turbidity can often indicate potential pollution, not just a decrease in water quality.

When entering in its downstream sectors, the Red River is split into several tributaries on both its sides including: the Tra Ly River that is $64 \mathrm{~km}$ long and located entirely in Thai Binh province; the Dao River that is $30 \mathrm{~km}$ long and located entirely in Nam Dinh province; the Ninh Co River that is $52.8 \mathrm{~km}$ long, a natural distributary of the Red River bringing water to the coastal of Nam Dinh province (NAWAPI 2016) and the main axis of the Red River (flowing to the Ba Lat estuary).

The river flowing through urban areas, industrial zones and canals in the towns is contaminated with varying levels. The water quality of the Red River is particularly important factor that needs to be studied and assessed timely due to the multi purposes of river water use. Indeed, the Red River currently is main water supply for industrial-agricultural activities and domestic use.

The main objectives of the present study are to assess water quality of the Red River downstream and to provide a dataset for subsequent studies on the annual variation of physical and chemical variables of the Red River water downstream, as well as the scientific basis for the effective protection and management of water resources in Vietnam.

\section{Materials and methods}

\subsection{Study area, sampling and methodology}

\subsubsection{Study area and sampling}

Surface water samples were collected at 5 sites on 4 distributaries of the Red River downstream: WS1 (Quyet Chien is located in the Tra Ly river, Thai Binh province); WS2 (Truc Phuong is located in the Ninh Co river, Nam Dinh province); WS3 (main axis of the Red River at Ba Lat estuary, Thai Binh province); WS4 (Nam Dinh is located in the Dao river, Nam Dinh province); WS5 (Gian Khau is located in the Day river, Ninh Binh province) as shown in the Figure 1. At each location, water samples were taken monthly during the period from January to December 2015.

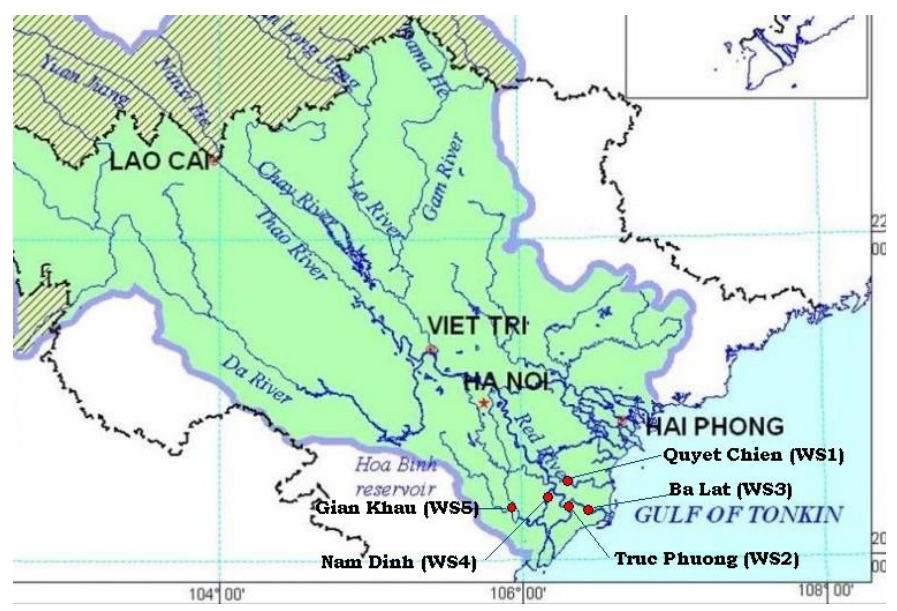

Figure 1. Site sampling location [Le, 2012]

\subsubsection{Methodology}

Physical chemical variables of water (temperature, $\mathrm{pH}$, and conductivity) were measured on site using a multi-variable probe (Model WQC-22 A, TOA). Water samples for determination of nutrients $\left(\mathrm{PO}_{4}{ }^{3-}-\mathrm{P}, \mathrm{NH}_{4}^{-}-\mathrm{N}, \mathrm{NO}_{3}{ }^{-}-\mathrm{N}, \mathrm{NO}_{2}^{-}-\mathrm{N}\right)$ were collected at surface layer, filtered through Whatman $\mathrm{GF} / \mathrm{C}$ filters $(0.47 \mu \mathrm{m})$ and kept in polypropylene bottles at $4^{\circ} \mathrm{C}$ in darkness and analyzed as soon as possible. The measurements were repeated three times and taken the average results ( $90 \%$ reliability).

\section{Results and discussion}

\subsection{Physical and chemical variables of water at downstream of Red river}

The results of physical and chemical variables of the Red River water downstream during the study period from January to December 2015 in the Red river are summarized in Table 1.

The water temperature was strongly seasonal and ranged from a minimum of $15^{\circ} \mathrm{C}$ in winter to a maximum of $34^{\circ} \mathrm{C}$ in summer. There was no significant difference in temperature between sampling sites. The mean temperatures at 5 sampling sites were around $26^{\circ} \mathrm{C}$. Water temperature followed a seasonal pattern in all stations that is typical for estuaries in this region. Temperature was lowest in January $\left(15^{\circ} \mathrm{C}-16^{\circ} \mathrm{C}\right)$, began to increase in April, and reached a maximum of $33^{\circ} \mathrm{C}-34^{\circ} \mathrm{C}$ in August. The average temperature of water remained in ranged of $27^{\circ} \mathrm{C}-28^{\circ} \mathrm{C}$ in September and October. Only in November, starting of winter in northern Vietnam, the water temperature rose slightly to $29^{\circ} \mathrm{C}$ (Fig 2a). This can be found on the vagaries of regional season. After which they decreased to $20^{\circ} \mathrm{C}$ in December. Among 5 sites there were no significant differences in temperature patterns throughout the year. The average $\mathrm{pH}$ for each sampling site are listed in Table 1 and ranged from 7.9 to 8.2 throughout the year. No significant differences existed in $\mathrm{pH}$ among all stations and the neutral $\mathrm{pH}$ values are presented in Figure 2b. Although WS5 in April had a $\mathrm{pH}$ value of 9.3, but it did not reflect the typical values for the entire station. No clear seasonal trend of $\mathrm{pH}$ was found at any of the sampling sites. 
Table 1: Physical and chemical variables of the Red River downstream water at 5 studied sites: combined observations from January to December 2015 (mean values and min-max values). Sites: WS1 (Quyet Chien); WS2 (Truc Phuong); WS3 (Ba Lat); WS4 (Nam Dinh); WS5 (Gian Khau)

\begin{tabular}{|c|c|c|c|c|c|c|c|c|c|c|c|c|}
\hline Sites & $\mathbf{p H}$ & $\begin{array}{c}\mathbf{T} \\
\left({ }^{\mathrm{o}} \mathrm{C}\right)\end{array}$ & $\begin{array}{c}\text { Turb. } \\
\text { (NTU) }\end{array}$ & $\begin{array}{c}\text { TDS } \\
(\mathrm{mg} / \mathrm{l})\end{array}$ & $\begin{array}{c}\text { Cond } \\
(\mu \mathrm{S} / \mathrm{cm})\end{array}$ & $\begin{array}{c}\mathrm{NO}_{2} \\
\mathrm{mgN} / \mathrm{l}\end{array}$ & $\begin{array}{c}\mathrm{NO}_{3} \\
\mathrm{mgN} / \mathrm{l}\end{array}$ & $\begin{array}{c}\mathrm{NH}_{4} \\
\mathrm{mgN} / \mathrm{l}\end{array}$ & $\begin{array}{l}\text { N total } \\
(\mathrm{mgN} / \mathrm{l})\end{array}$ & $\begin{array}{c}\mathrm{Si} \\
\mathrm{mgSi} / \mathbf{l}\end{array}$ & $\begin{array}{l}\mathrm{PO}_{4}-\mathrm{P} \\
\mathrm{mgP} / \mathrm{l}\end{array}$ & $\begin{array}{l}\mathrm{P} \text { total } \\
\mathrm{mgP}_{4} \mathbf{l}\end{array}$ \\
\hline $\begin{array}{l}\text { WS1 } \\
\text { (mean) }\end{array}$ & 8.2 & 26.8 & 115.4 & 135.2 & 193.37 & 0.024 & 0.79 & 0.048 & 0.865 & 4.64 & 0.03 & 0.20 \\
\hline $\begin{array}{c}\min - \\
\max \end{array}$ & $\begin{array}{l}7.9- \\
8.5\end{array}$ & $18-33$ & $12-1,041$ & $96-179$ & $139-257$ & $\begin{array}{c}0.002- \\
0.159\end{array}$ & $\begin{array}{c}0.36- \\
1.31\end{array}$ & $\begin{array}{c}0.002- \\
0.118\end{array}$ & $\begin{array}{c}0.385- \\
1.474\end{array}$ & $\begin{array}{c}3.75- \\
5.68\end{array}$ & $\begin{array}{c}0.003- \\
0.182\end{array}$ & $0.39-0.924$ \\
\hline $\begin{array}{c}\text { WS2 } \\
\text { (mean) }\end{array}$ & 8.1 & 26.4 & 60 & 125.4 & 179.04 & 0.01 & 0.85 & 0.06 & 0.92 & 4.67 & 0.02 & 0.20 \\
\hline$\underset{\max }{\min -}$ & $\begin{array}{l}7.8- \\
8.4\end{array}$ & $16-33$ & $2-348$ & $\begin{array}{c}94.9- \\
150\end{array}$ & $\begin{array}{c}135.8- \\
216\end{array}$ & $\begin{array}{c}0.00- \\
0.03\end{array}$ & $\begin{array}{c}0.32- \\
1.70\end{array}$ & $\begin{array}{c}0.00- \\
0.18\end{array}$ & $0.37-1.70$ & $\begin{array}{c}3.87- \\
5.66\end{array}$ & $\begin{array}{c}0.00- \\
0.12\end{array}$ & $0.04-0.53$ \\
\hline $\begin{array}{c}\text { WS3 } \\
\text { (mean) }\end{array}$ & 7.9 & 26.4 & 44.2 & 451.2 & 268.2 & 0.03 & 0.51 & 0.086 & 0.63 & 3.74 & 0.02 & 0.16 \\
\hline$\underset{\max }{\min -}$ & $\begin{array}{l}7.3- \\
8.3\end{array}$ & $15-33$ & $11-155$ & $\begin{array}{l}1.44- \\
3,160\end{array}$ & $\begin{array}{l}2.07- \\
1,028\end{array}$ & $\begin{array}{c}0.00- \\
0.12\end{array}$ & $\begin{array}{c}0.21- \\
1.5\end{array}$ & $\begin{array}{c}0.01- \\
0.19\end{array}$ & $0.32-1.57$ & $\begin{array}{l}2.1- \\
5.53\end{array}$ & $\begin{array}{c}0.00- \\
0.12\end{array}$ & $0.03-0.29$ \\
\hline $\begin{array}{c}\text { WS4 } \\
\text { (mean) }\end{array}$ & 8.2 & 26.9 & 91.8 & 132.6 & 180.0 & 0.04 & 0.81 & 0.085 & 0.93 & 4.65 & 0.03 & 0.16 \\
\hline $\begin{array}{l}\min - \\
\max \end{array}$ & $\begin{array}{l}7.8- \\
8.4\end{array}$ & $17-33$ & $11-651$ & $\begin{array}{l}102.1- \\
150.9\end{array}$ & $\begin{array}{l}105.2- \\
213\end{array}$ & $\begin{array}{c}0.00- \\
0.19\end{array}$ & $\begin{array}{c}0.15- \\
1.38\end{array}$ & $\begin{array}{c}0.00- \\
0.35\end{array}$ & $0.40-1.57$ & $\begin{array}{c}3.64- \\
5.64\end{array}$ & $\begin{array}{c}0.01- \\
0.10\end{array}$ & $0.05-0.56$ \\
\hline $\begin{array}{c}\text { WS5 } \\
\text { (mean) }\end{array}$ & 8.0 & 26.2 & 53.6 & 217.8 & 313.3 & 0.08 & 1.17 & 0.16 & 1.41 & 3.60 & 1.18 & 0.17 \\
\hline $\begin{array}{l}\min - \\
\max \end{array}$ & $\begin{array}{l}7.4- \\
9.3\end{array}$ & $16-34$ & $14-161$ & $\begin{array}{l}170- \\
269\end{array}$ & $243-378$ & $\begin{array}{c}0.00- \\
0.64\end{array}$ & $\begin{array}{c}0.46- \\
1.92\end{array}$ & $\begin{array}{c}0.00- \\
1.12\end{array}$ & $0.49-2.57$ & $\begin{array}{c}0.53- \\
5.20\end{array}$ & $\begin{array}{c}0.17- \\
1.70\end{array}$ & $0.07-0.39$ \\
\hline $\begin{array}{c}\mathrm{QCVN} \\
*\end{array}$ & $5.5-9$ & - & - & - & - & 0.05 & 10 & 0.9 & - & - & 0.3 & - \\
\hline
\end{tabular}

* QCVN 08-MT:2015/BTNMT (B1): the permissible maximum value in surface water for the irrigation purposes, waterway and other purposes with low quality water requirements.

The turbidity (Turb) values showed in table 1 with average values recorded at WS1, WS2, WS3, WS4 and WS5 were $115.4 \mathrm{mg} / \mathrm{L}, 60 \mathrm{mg} / \mathrm{L}, 44.2 \mathrm{mg} / \mathrm{L}, 91.8 \mathrm{mg} / \mathrm{L}$ and 53.6 $\mathrm{mg} / \mathrm{L}$, respectively. The highest concentration of turbidity occurred at WS1 (1041 NTU) in October has made the average value of Turb higher than other sites. The lowest concentrations recorded in WS3 and WS4 at the same value of 11 NTU. There were no significant differences in turbidity patterns among 5 stations throughout the year, except for March and August (Figure 2c). The concentration of turbidity recorded at WS4 (153NTU) and WS5 (161NTU) were slightly higher in March. Also at WS2 and WS3 in August, the obtained values of turbidity concentrations were 174 NTU and 142 NTU, respectively. Particularly in October, the highest values of turbidity obtained at 4 stations WS1, WS2, WS3 and WS4 were 1041 NTU, 348 NTU, 155 NTU and 651 NTU, respectively. Unusually high values of turbidity at 4 stations were measured in October due to the increase rainfall because of the rainy season in the northern Vietnam. A sudden increase in turbidity in a previously clear body of water is a cause for concern. Excessive suspended sediment can impair water for aquatic and human life, impede navigation (Wood, M. S. 2014).

Throughout the year, the average conductivity at WS1, WS2 and WS4 were $193.4,179.0$ and $180.0 \mathrm{mg} / \mathrm{L}$, respectively (Table 1). The distribution of conductivity among sampling sites showed variability that it was higher in WS3 $(268.2 \mathrm{mg} / \mathrm{L})$ and WS5 $(313.3 \mathrm{mg} / \mathrm{L})$ than the ones in the other sites. Water level changes, such as tidal stages and evaporation will cause salinity and conductivity levels to fluctuate as well at WS3 (Ba Lat estuary). The sampling site WS5 (Gian Khau) located in Day River receiving water from Nhue-ToLich River that contains urban wastewater (including domestic wastewater of Hanoi capital). Besides, this site is also affected by shipping traffic, industrial and agriculture activities. Therefore, the addition of phosphate and nitrate ions caused by agricultural runoff and sewage leakage also contribute to increase conductivity at WS5 (Gian Khau).

There were no differences in conductivity and total dissolved solids (TDS) among three stations WS1, WS2 and WS4 (Figure 2d-e). The values of conductivity and TDS ranged from 105 to $257 \mu \mathrm{S} / \mathrm{cm}$ and from 95 to $179 \mathrm{mg} / \mathrm{L}$, respectively. At station WS5, conductivity was in range of high values $(243-378 \mu \mathrm{S} / \mathrm{cm})$ because of production activities from industrial zones and Gian Khau port located in this site. Fluctuations in conductivity and TDS occurred only at station WS3. The lowest and highest values of conductivity and TDS were recorded at WS3 $(2.1-1028 \mu \mathrm{S} / \mathrm{cm}$ and $3.7-3160 \mathrm{mg} / \mathrm{L}$ ), respectively. This can be explained by the position of sampling stations located at the estuary have been affected by the tidal. Unlike temperature, conductivity and TDS varied geographically, decreasing with respect to the freshwater inputs, and increasing probably due to intrusion of high salinity water from the Gulf of Tonkin. Throughout the year, the average total dissolved solids (TDS) at 5 study sites varied between $125.4 \mathrm{mg} / \mathrm{L}$ and $451.2 \mathrm{mg} / \mathrm{L}$. The TDS fluctuations occurred in WS3 (Ba Lat estuary) and ranged from minimum value of $1.44 \mathrm{mg} / \mathrm{L}$ to maximum value of $3,160 \mathrm{mg} / \mathrm{L}$ due to the tide effects (Table 1). 

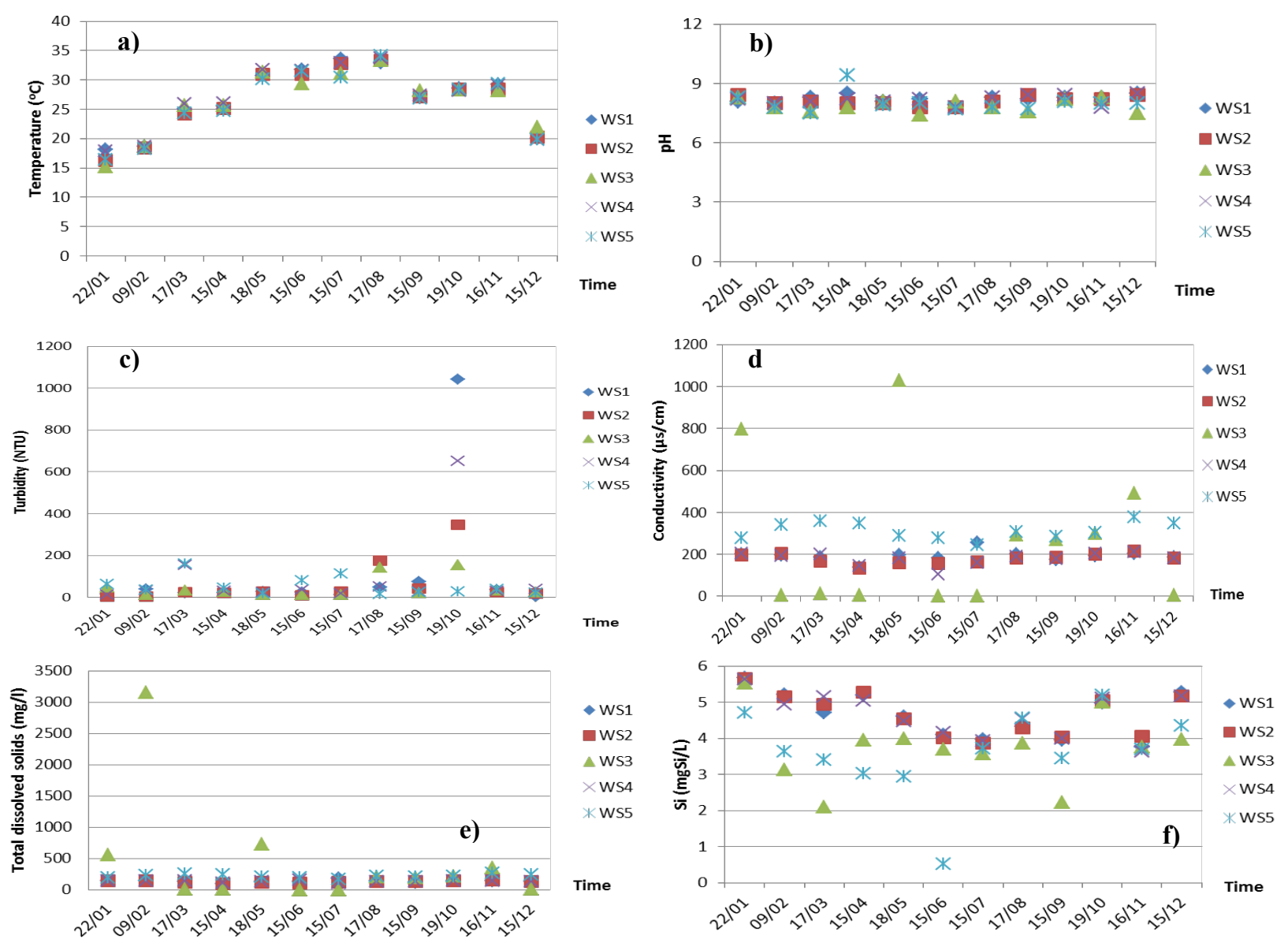

Figure 2. Temperature, pH, turbidity, conductivity, total dissolved solids and silica trends for each stations of Red River downstream for January through December 2015

Table 1 shows that the variations of Silica $(\mathrm{Si})$ concentrations in the downstream were not significant. The average values of $\mathrm{Si}$ range from $3.6 \mathrm{mgSi} / \mathrm{L}$ to $4.6 \mathrm{mgSi} / \mathrm{L}$ among all sampling sites. The distribution pattern of $\mathrm{Si}$ along the downstream was similar throughout the year at WS1, WS2 and WS4 (Fig 2f). Fluctuations of Si concentrations occurred at stations WS3 and WS5, with the lowest values were $2.1 \mathrm{mgSi} / \mathrm{L}$ and $0.53 \mathrm{mgSi} / \mathrm{L}$; the highest values were $5.53 \mathrm{mgSi} / \mathrm{L}$ and $5.2 \mathrm{mgSi} / \mathrm{L}$, respectively. Si concentrations were slight decreased in the rainy season (from May to September).

\subsection{Nutrients}

In downstream area of Red River, nutrients (N, P) mainly come from fertilizers on the fields and from anthropological waste, so the variation of nutrient concentrations in the rivers is complicated. The high concentration of nutrients comes from the populated centres where the wastewater discharged directly into the river ( $\mathrm{Vu}$ Huu Hieu et al, 2010). Table 1 shows the high concentrations of average phosphate was measured at WS5 $(1.18 \mathrm{mgP} / \mathrm{L})$ that accurately reflected the geography of the site locating in Day river where was strong affected by human activities. Also the average total inorganic nitrogen (TN) concentration in WS5 recorded at $1.41 \mathrm{mg} / \mathrm{L}$ was the highest level among the all sites. In other sampling sites, average concentrations of nitrate, ammonium, phosphate and total phosphate ranged from $0.5-0.85 \mathrm{mgN} / \mathrm{L} ; 0.04-0.085 \mathrm{mgP} / \mathrm{L} ; 0.02-$ $0.03 \mathrm{mgP} / \mathrm{L}$, and $0.16-0.20 \mathrm{mgP} / \mathrm{L}$, respectively. Overall, there were no significant difference in nutrient concentrations between sampling stations and seasons.

Concentrations of dissolved ammonium, nitrate and nitrite in downstream of the Red River are depicted in Fig.3. No significant differences existed in $\mathrm{NH}_{4}{ }^{+}$and $\mathrm{NO}_{3}{ }^{-}$among all stations, although the maximum $\mathrm{NH}_{4}{ }^{+}$concentration was $1.18 \mathrm{mgN} / \mathrm{L}$ occurring at WS5 in November but it did not reflect the typical values for the entire station. Concentrations of $\mathrm{NO}_{3}{ }^{-}$in samples collected at all stations during the year 2015 were relatively constant, ranged from $0.21-1.92 \mathrm{mgN} / \mathrm{L}$ and lower than permissible limit value QCVN08:2015.

The concentrations of $\mathrm{NO}_{2}{ }^{-}$in the downstream do not differ significantly among all the sampling sites. Almost of $\mathrm{NO}_{2}^{-}$ concentrations recorded were less than $0.5 \mathrm{mgN} / \mathrm{L}$ and reached the permissible limit QCVN08:2015 (Fig 3). However, at WS5 site, $\mathrm{NO}_{2}^{-}$values were high concentration in July $(0.083 \mathrm{mgN} / \mathrm{L})$, in August $(0.134 \mathrm{mgN} / \mathrm{L})$ and November $(0.642 \mathrm{mgN} / \mathrm{L})$. The highest nitrite concentrations measured in November at 4 stations WS1, WS3, WS4 and WS5 were $0.159 \mathrm{mgN} / 1,0.053 \mathrm{mgN} / 1$, $0.192 \mathrm{mgN} / 1$ and $0.642 \mathrm{mgN} / 1$, respectively which exceeded the permissible limit QCVN08:2015.

Total nitrogen $(\mathrm{TN})$ is often a variable considered when estimating potential downstream effects of $\mathrm{N}$ to receiving water such as the study region (Heiskary et al., 2010). Figure 3 shows that, almost of TN concentrations ranged from 
0.4 to $2.0 \mathrm{mg} / \mathrm{L}$. As $\mathrm{TN}$ increases above $2 \mathrm{mg} / \mathrm{l}$, nitrate-N becomes an important component to TN. The results indicated the highest value of TN $2.6 \mathrm{mg} / \mathrm{L}$ in November at station WS5 that also was the highest TN concentration in among all stations throughout the year. In general,
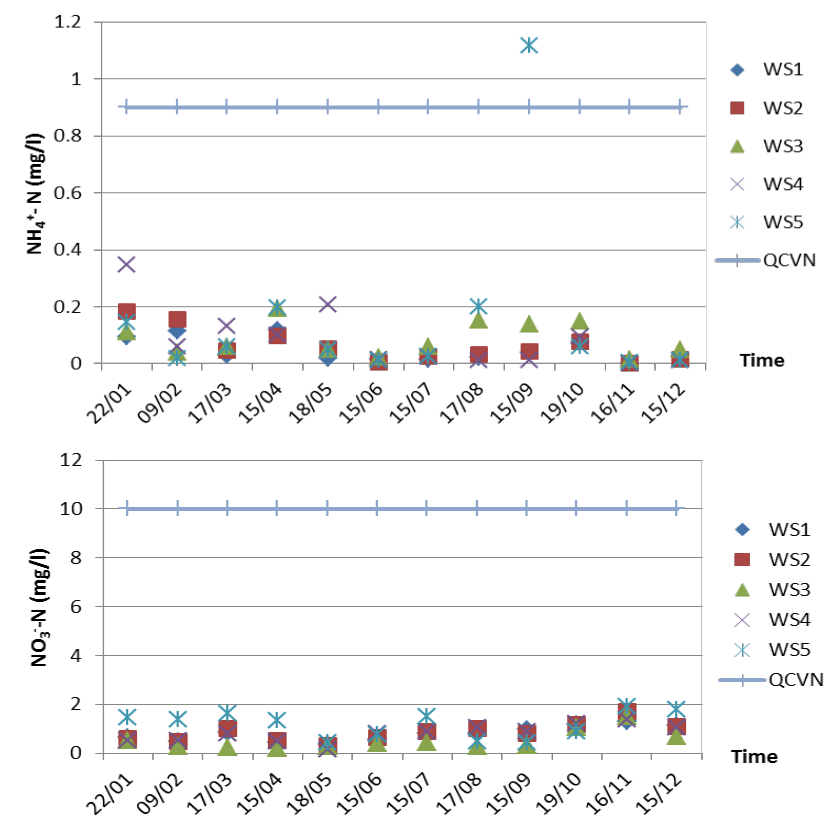

Figure 3. Nitrite, nitrate, ammonium and N-total concentrations trends for each stations of Red River downstream for January through December 2015

Figure 4 shows the distributions and variations of $\mathrm{P}$ in the Red River downstream throughout the year 2015. The site WS5 effected by results in intensive anthropogenic disturbance, through industrial and agricultural production, municipal sewage, etc. Therefore, high concentrations of PO4-P ranged from $1.17-1.7 \mathrm{mgP} / \mathrm{L}$ throughout the year and exceeded the permissible limit QCVN08:2015. The average concentrations of PO4-P in other sites were low throughout the year and below the permissible limit (Table $1)$.

Total phosphorus (TP) distribution showed variation values among 5 sampling sites and did not display clear seasonal trends (Figure 4). The highest TP concentrations occurred in October at WS1 and WS4 $(0.924$ and $0.56 \mathrm{mgP} / \mathrm{L}$, respectively). While the highest TP concentrations at other sites occurred in March and May. Rest of TP concentrations recorded throughout the year at 5 stations have lower values $0.3 \mathrm{mgP} / \mathrm{L}$. In detail, the lowest value of TP recorded at station WS2 was $0.04 \mathrm{mgP} / \mathrm{L}$ in January, at WS3 station was $0.03 \mathrm{mgP} / \mathrm{L}$ in January and at WS4 station was $0.05 \mathrm{mgP} / \mathrm{L}$ in April.

The results of physical and chemical variables of the Red River water downstream recorded in 2015 showing that the water quality at some sampling sites have occurred risk of pollution in a few the month of the year. However, because the river flows very large, contaminants have been diluted and cleaned after a short distance (NAWAPI 2016). concentrations of dissolved ammonium, nitrate, nitrite and $\mathrm{TN}$ in downstream of Red River did not display clear seasonal trends.

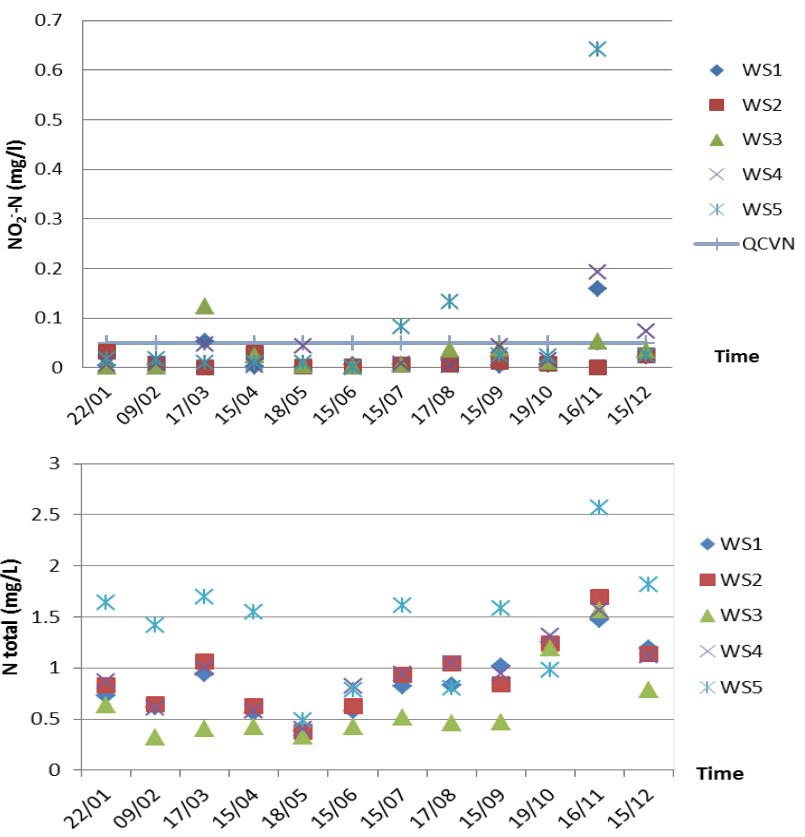

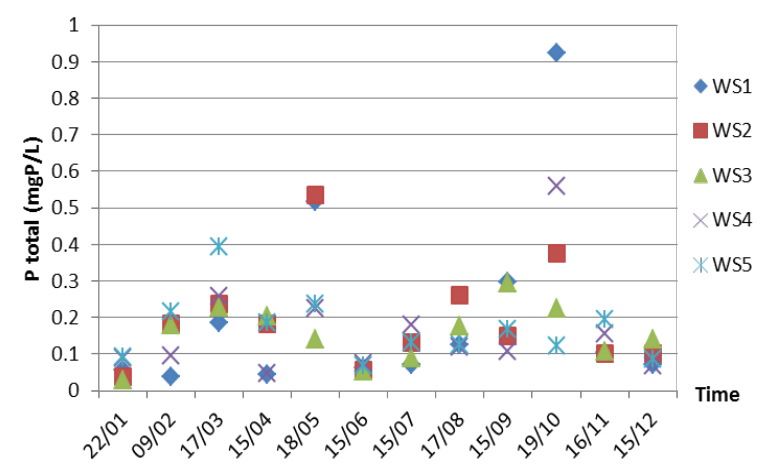

Figure 4. Phosphorus concentrations trends of Red River downstream for January through December 2015 


\section{Conclusions}

From the actual survey results and analysis results of water samples showed that almost the data about water quality at downstream of the Red River were under the permitting limit values of the National technical regulation on surface water quality (QCVN 08:2015, column B1). Water quality at downstream of the Red River reached the permissible value in surface water for the irrigation purposes, waterway and other purposes with low quality water requirements.

The study and assessment of water quality of the Red River downstream in detail, and the entire Red River system in generally, need to be studied for long term. The data collected will timely warn the risk of contaminating the Red River water quality and contribute to the protection and management of the water resources of Vietnam.

\section{Acknowledgements}

This work was supported by the NAFOSTED (106NN.992014.20 project, the IFS W/4674-2 and the ARCP201403CMY-Quynh/ARCP2013-06CMY-Quynh/ARCP201211NMY-Quynh projects. The authors are grateful for the financial supports from Vietnam's National Foundation for Science and Technology Development (NAFOSTED), the International Foundation for Science (IFS) and the AsiaPacific Network for Global Change Research (APN). The authors thank many individuals for their help in collecting samples in the field.

\section{References}

[1] APHA (1998) American Public Health Association. American Water Works Association (AWWA), Water Environment Federation (WEF). Standard methods for the examination of water and wastewater, 20th edn. American Public Health Association, Washington.

[2] Heiskary, S., Bouchard, R.W., Markus, H. (2010)
Minnesota Nutrient Criteria Development for Rivers [DRAFT]. Minnesota Pollution Control Agency. 102 pp.

[3] Le, T.P.Q., Billen, G., Garnier, J., Thery, S., Fezard, C., Chau, V.M (2005). Nutrient (N, P) budgets for the Red River basin (Vietnam and China). Global Biogeochem Cycles 19(2): 1-16.

[4] Le, T.P.Q., Garnier, J., Billen, G., Thery S., Chau, V.M (2007) The changing flow regime and sediment load of the Red River, Viet Nam. J Hydrology 334 : 199-214.

[5] Le, V. C. (2012) Return flow and reuse of drainage water in a rice-based irrigation and drainage area in the Red River Basin, Vietnam, PhD dissertation, 1157. Department of Basic Sciences and Environment, University of Copenhagen, Denmark.

[6] Luu, T.N.M., Garnier, J., Billen, G., Orange, D., Nemery, J., Le, T.P.Q., Tran, H.T., Le, LA (2010) Hydrological regime and water budget of the Red River Delta (Northern Vietnam). Journal of Asian Earth Sciences. 37: 219-228.

[7] National Centre for Water Resources Planning and Investigation (NAWAPI), MONRE (2016) The water resources planning in Hong-Thai Binh River basin.

[8] Perlman, H. (2014) Turbidity. In The USGS Water Science School.

[9] Vu, H. H., Le, T.P.Q., Josette, G., Etcheber, H., Duong, T.T., Ho, T.C. (2012) Preliminary observation of particulate organic carbon (POC) contents in water environment of the downstream Red River system. Vietnam Journal of Earth Sciences. 34 (1), 1017.

[10] Wood, M. S. (2014) Estimating suspended sediment in rivers using acoustic Doppler meters. In U.S. Geological Survey Fact Sheet 2014-3038. N.p.: U S Geological Survey. 